\title{
SKRINING HIV PADA REMAJA DI SURABAYA DENGAN MENGGUNAKAN RAPID TEST
}

\author{
Thomas S. ${ }^{1)}$, Rahayu A. ${ }^{1)}$, Handayani' ${ }^{2}$, M. Yusuf Alamudi ${ }^{3,4,5)}$ \\ ${ }^{1}$ Analis Kesehatan-Universitas Nadhlatul Ulama Surabaya \\ ${ }^{2}$ Fakultas Kedokteran-Universitas Nadhlatul Ulama Surabaya \\ ${ }^{3}$ Pusat Riset Flu Burung-Universitas Airlangga \\ ${ }^{4}$ Fakultas Kesehatan Masyarakat-Universitas Nadhlatul Ulama Surabaya \\ ${ }^{5}$ Pusat Penelitian Kesehatan Pondok Pesantren-Universitas Nadhlatul Ulama Surabaya \\ e-mail:
}

\begin{abstract}
Abstrak: HIV (Human Immunodeficiency Virus) merupakan retrovirus bersifat limfotropik khas yang menginfeksi sel-sel dari sistem kekebalan tubuh, menghancurkan atau merusak sel darah putih spesifik yang disebut limfosit T-helper atau limfosit pembawa faktor T4 (CD4). Virus ini diklasifikasikan dalam famili Retroviridae, subfamili Lentiviridae, genus Lentivirus. Jumlah kematian HIV/AIDS di kalangan remaja di seluruh dunia yang meningkat sebesar 50 persen antara tahun 2005 dan 2012 menunjukkan tren mengkhawatirkan. Laporan badan PBB yang menangani masalah anak-anak UNICEF menyebutkan sekitar 71.000 remaja berusia antara 10 dan 19 tahun meninggal dunia karena virus HIV pada tahun 2005. Jumlah itu meningkat menjadi 110.000 jiwa pada tahun 2012. Unit Perawatan Intermediet dan Penyakit Infeksi (UPIPI) RSUD dr. Soetomo Surabaya. 1.780 pasien yang rutin berobat di UPIPI, sedangkan jumlah pengunjung setiap bulannya mencapai 2.000 orang, yakni 50 di antaranya adalah pasien anak-anak dan sisanya dewasa. Kebanyakan pasien berumur antara 20 hingga 30 tahun dari berbagai wilayah yang tersebar di Jatim, seperti Surabaya, Sidoarjo, Gresik, Jember, maupun Pasuruan. Tujuan dari penelitian ini mendeteksi virus HIV pada remaja di Surabaya dengan menggunakan rapid test. Sebanyak 54 orang remaja di Surabaya diambil darahnya, dipisahkan dan dicek dengan menggunakan rapid test. Prosedur mengikuti manual rapid test. Hasil penelitian menunjukkan bahwa dari 54 sampel dengan menggunakan rapid test menunjukkan hasil negatif terhadap HIV.
\end{abstract}

Kata Kunci: skrining, HIV, rapid test, remaja, Surabaya

\section{PENDAHULUAN}

HIV merupakan singkatan dari Human Immunodeficiency Virus (HIV) merupakan retrovirus yang menjangkiti sel-sel sistem kekebalan tubuh manusia (terutama CD4 positif Tsel dan makrofag- komponen-komponen utama sistem kekebalan sel), dan menghancurkan atau mengganggu fungsinya. Infeksi virus ini mengakibatkan terjadinya penurunan sistem kekebalan yang terus-menerus, yang akan mengakibatkan defisiensi kekebalan tubuh. Sistem kekebalan dianggap defisien ketika sistem tersebut tidak dapat lagi menjalankan fungsinya memerangi infeksi dan penyakit-penyakit. Orang yang kekebalan tubuhnya defisien (Immunodeficient) menjadi lebih rentan terhadap berbagai ragam infeksi, yang sebagian besar jarang menjangkiti orang yang tidak mengalami defisiensi kekebalan. Virus HIV diklasifikasikan ke dalam golongan lentivirus atau retroviridae. Virus ini secara material genetik adalah virus RNA yang tergantung pada enzim reverse transcriptase untuk dapat menginfeksi sel mamalia, termasuk manusia, dan menimbulkan kelainan patologi secara lambat. Virus ini terdiri dari 2 grup, yaitu HIV1 dan HIV-2. Masing-masing grup mempunyai 
lagi berbagai subtipe, dan masing-masing subtipe secara evolusi yang cepat mengalami mutasi. Di antara kedua grup tersebut, yang paling banyak menimbulkan kelainan dan lebih ganas di seluruh dunia adalah grup HIV-1 (Zein, 2006).

Profil Kesehatan Indonesia tahun 2013 menyebutkan, setelah tiga tahun berturut-turut (2010-2012) jumlah kasus HIV cukup stabil, tapi perkembangan “jumlah kasus baru HIV positif pada tahun 2013 kembali mengalami peningkatan secara signifikan, dengan kenaikan mencapai 35\% dibanding tahun 2012\%. (3) Serta mengalami peningkatan kembali pada tahun 2014. Berdasarkan data Profil Kesehatan RI, jumlah kasus HIV positif pada tahun 2012 sebanyak 21.511 kasus, meningkat 34,9\% pada tahun 2013 (29.037 kasus), serta pada tahun 2014 meningkat lagi 12,36\% (32.711 kasus), dan tahun 2015 sebanyak 30.935 kasus dengan penurunan 5,42\%. Persentase kumulatif infeksi HIV tertinggi dilaporkan pada kelompok umur 20-24 tahun 4.871 kasus (17\%), umur 25-49 tahun 21.810 (69\%) dan kelompok umur di atas 50 tahun 2.002 kasus (7\%). (4) Laporan kasus AIDS yang didapatkan sampai tahun 2015, terjadi peningkatan $7.8 \%$ pada tahun 2013 , dan terjadi penurunan pada tahun berikutnya. Kasus AIDS pada tahun 2012 (10.659 kasus), meningkat 7,8\% pada tahun 2013 (11.493 kasus), menurun 31,4\% pada tahun 2014 (7.875 kasus) dan pada tahun 2015 terjadi penurunan lagi 22,7\% (6.081 kasus). Dengan kelompok umur 20-29 tahun 27,9\% kasus, 30-39 tahun 37,3\% kasus, 40-49 tahun 18,8\% kasus dan di atas 60 tahun 2\% kasus. (4) Berdasarkan data yang ada sepuluh provinsi terbanyak kasus AIDS tertinggi di urutan pertama yaitu Bali (955 kasus), diikuti Bengkulu (586 kasus), Gorontalo (212 kasus), DKI Jakarta (171 kasus), Bangka Belitung (152 kasus), Sumatera Selatan (120 kasus), Papua (119 kasus),
NTT (112 kasus), Sumbar (97 kasus), dan Sulawesi Selatan (92 kasus). (4) Angka kematian akibat AIDS di Indonesia berdasarkan laporan yang ada, pada tahun 2012 (2.072 kasus), tahun 2013 (1.481 kasus), tahun 2014 (956 kasus) dan pada tahun 2015 (610 kasus) yang di laporkan. Dengan kelompok umur 15-19 tahun 209 kasus, umur 20-29 tahun 3.877 kasus.

Kasus HIV/AIDS pada remaja setiap tahun selalu mengalami peningkatan. Hal ini juga didukung dengan perkembangan globalisasi yang mengakibatkan adanya perubahan sosial dan gaya hidup remaja, termasuk perilaku berisiko seperti hubungan seksual dengan berganti-ganti pasangan, hubungan seks pranikah, serta penyalahgunaan narkoba. Gaya hidup seperti ini membahayakan kesehatan reproduksi terutama kemungkinan terjadinya penularan penyakit menular seksual termasuk HIV (Human Immunodeficiency Virus)/AIDS (Acquerid Immuno Deficiency Syndrome) pada pasangannya. Remaja merupakan kelompok yang rentan terhadap IMS (Infeksi Menular Seksual) dengan jumlah terbesar mengidap HIV/AIDS. Remaja merupakan sasaran primer dalam program penanggulangan IMS khususnya HIV/AIDS (Soetjiningsih, 2007). Remaja mengalami perubahan yang mencakup perubahan fisik dan emosional yang kemudian tecermin dalam sikap dan tingkah laku. Remaja merupakan salah satu kelompok penduduk yang mudah terpengaruh oleh arus informasi baik informasi yang positif maupun yang negatif. Hal-hal negatif seperti seks dan narkoba, selain dapat menimbulkan kehamilan yang tidak diinginkan dan kematian akibat overdosis juga memberikan risiko yang tinggi dalam penularan HIV/AIDS pada remaja (UNAIDS, 2002). Kementerian Kesehatan melaporkan bahwa pada 3 tahun terakhir terhitung tahun 2010 sampai dengan 2013 terjadi peningkatan kasus baru 
HIV/AIDS yang semakin cepat di Jawa Timur dengan persentase kasus yang terjadi pada lakilaki lebih tinggi daripada kasus yang dialami oleh perempuan. Secara kumulatif kasus HIV \& AIDS di Jawa Timur menduduki peringkat kedua setelah Papua dengan persentase kasus HIV (14,285 kasus) dan kasus AIDS (6,900 kasus) (Kemenkes, 2013). Pada Juni 2013 Direktorat Jenderal Pengendalian Penyakit \& Penyehatan Lingkatam Kementerian Kesehatan RI secara statistik melaporkan jumlah kumulatif kasus HIV/AIDS menurut faktor risiko, penyebaran HIV/AIDS ditularkan melalui hubungan seks heteroseksual berada pada peringkat pertama dengan persentase 26,156 kasus, dan pula didapati jumlah kumulatif kasus HIV/AIDS berdasarkan golongan umur 15-19 tahun sebanyak 1,416 kasus. Tujuan penelitian ini adalah menskrining virus HIV pada remaja yang memiliki latar belakang pondok pesantren di Surabaya.

\section{BAHAN DAN METODE}

Pengambilan sampel dilakukan pada remaja dengan usia 19-20 tahun dengan tidak membedakan jenis kelamin. Serum yang telah dipisahkan diteteskan pada monotes rapid test untuk pengujian HIV dan selanjutnya mengikuti prosedur dari monotes rapid test HIV.

\section{HASIL PENELITIAN DAN PEMBAHASAN}

Dari hasil penelitian yang dilakukan dengan menggunakan monotes rapid test HIV didapatkan hasil bahwa remaja dengan memiliki latar belakang pondok pesantren di Surabaya negatif terhadap HIV dengan menggunakan rapid test HIV monotes. Hasil pengujian dengan menggunakan rapid test sebagai berikut.

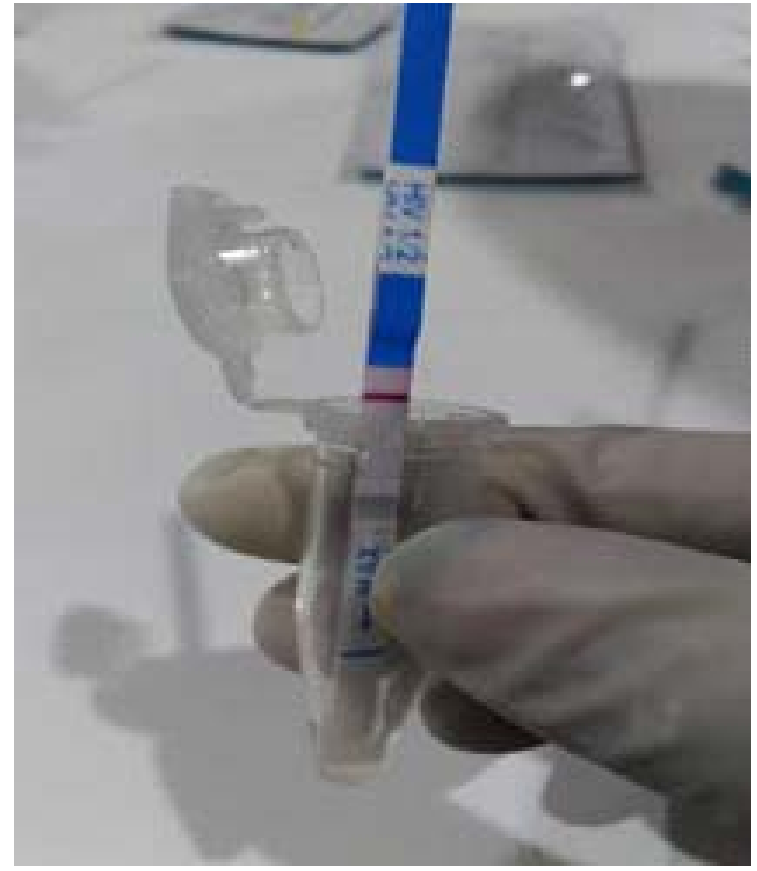

Gambar 1 Pengujian Serum pada Sampel Terhadap HIV dengan rapid test

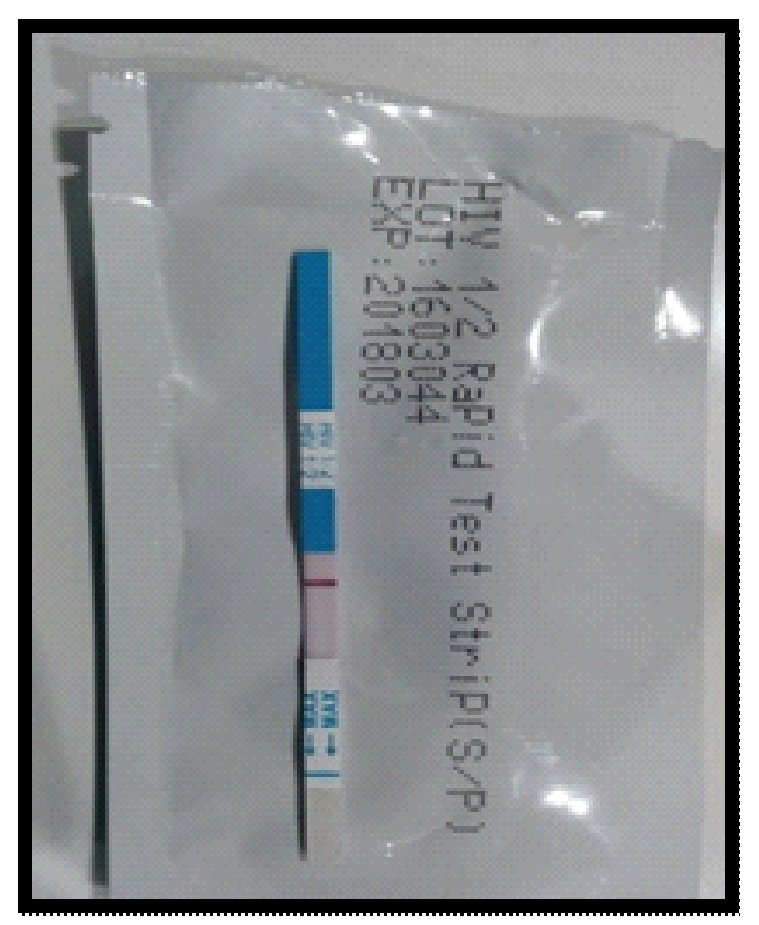

Gambar 2 Hasil Pengujian dengan Menggunakan Rapid Test

Human Immunodeficiency Virus (HIV) adalah virus yang menyebabkan Acquired Immuno Deficiency Syndrome (AIDS). Sedangkan AIDS 
adalah suatu penyakit yang ditandai dengan melemahnya sistem kekebalan tubuh. Dengan melemahnya kekebalan ini maka tubuh tak mampu lagi mempertahankan dirinya terhadap serangan penyakit. HIV/AIDS merupakan masalah kesehatan global baik di negara maju maupun negara berkembang. Wilayah terburuk yang terinfeksi virus HIV adalah Afrika Sub-Sahara, Asia Selatan, dan Asia Tenggara. Indonesia merupakan negara yang tingkat penyebaran virus HIV/AIDSnya tercepat di Asia. Epidemi HIV/AIDS di Indonesia telah berlangsung lebih dari 20 tahun, dan sejak tahun 2000 fase epidemiknya sudah berubah dari tingkat low menjadi tahap concentrated epidemic (prevalensi lebih dari 5\%) pada sub populasi berisiko tinggi yaitu pengguna NAPZA suntik (Penasun), wanita penjaja seks (WPS), pelanggan penjaja seks, lelaki seks dengan lelaki lain dan waria. Selain itu, menurut data 2010, baik dari Badan Pusat Statistik (BPS), Bappenas dan UNFPA, sebagian dari 63 juta jiwa remaja berusia 10 sampai 24 tahun di Indonesia rentan berperilaku tidak sehat. Masalah yang paling menonjol di kalangan remaja saat ini, misalnya masalah seksualitas, kemudian rentan terinfeksi penyakit menular seksual (IMS), HIV atau AIDS serta penyalahgunaan narkoba.

Berdasarkan hasil penelitian yang dilakukan dengan menggunakan rapid test terhadap HIV pada remaja di Surabaya yang memiliki latar belakang pendidikan pondok pesantren, didapatkan hasil negatif terhadap HIV. Hasil penelitian ini memiliki perbedaan dengan penelitian yang dilakukan oleh Sri Harti, dkk. (2014) penelitian dilakukan di salah rumah sakit Surakarta dengan jumlah sampel 20 buah dengan menggunakan rapid test di dalam mendeteksi HIV, berdasarkan hasil pemeriksaan HIV 1 dan 2 metode imunokromatografi rapid test terhadap 20 sampel pasien tersangka AIDS didapatkan 5 sampel yang menunjukkan positif mengandung antibodi HIV1 dan 2. Selain itu, berdasarkan hasil penelitian yang dilakukan oleh Aroem Naroeni, dkk. (2009) bahwa pada sampel plasma yang mempunyai hasil uji serologi indeterminate dari donor darah yang diambil dari Unit Transfusi Darah Pusat, Palang Merah Indonesia (PMI) dan dilakukan uji konfirmasi dengan menggunakan western blot. Hasil pengujian dari 40 sampel menunjukkan 90\% sampel terkonfirmasi sebagai indeterminate. Sebagian besar hasil indeterminate dihasilkan oleh reaksi dengan antigen p24 virus HIV. RT-PCR dengan target daerah LTR, pol, env dan p24 dilakukan untuk mendeteksi adanya RNA HIV. Primer kemudian didesain untuk mengamplifikasi daerah tersebut. Sebanyak 24/ 32 atau 75\% sampel positif LTR, 4/31 atau 12\% positif pol dan 3/5 atau 60\% positif env. Amplifikasi pada daerah p24. Hasil penelitian ini juga memiliki perbedaan dengan penelitian yang dilakukan Andi Yasmon, dkk. (2010) bahwa metode Uji RT-PCR dievaluasi terhadap 46 spesimen yang diperoleh dari voluntary counseling and testing for HIV (VCT) di Rumah Sakit Umum Pemerintah (RSUP) Sanglah, Bali. Untuk mendapatkan sensitivitas dan spesivitas uji, hasil uji RT-PCR dibandingkan dengan hasil serologi yang umum digunakan di Indonesia. Hasil Uji RTPCR dapat mendeteksi 21dari 26 spesimen yang positif uji serologi dan memberikan 19 hasil uji negatif dari 20 spesimen yang negatif uji serologi. Satu spesimen menunjukkan hasil positif dengan RT-PCR tetapi negatif dengan uji serologi. Hasil tersebut kemungkinan menggambarkan hasil yang sebenarnya saat uji serologi tidak dapat mendeteksi infeksi HIV-1. Selain itu, lima spesimen yang positif uji serologi menunjukkan hasil negatif dengan RT-PCR yang diduga disebabkan oleh batas deteksi uji RT-PCR yang 
rendah. Hasil penelitian yang dilakukan oleh Rosilawati dan Bela (2007) menyatakan bahwa penelitian dengan menggunakan serum darah dari Rumah Sakit Ketergantungan Obat (RSKO) Fatmawati. Jumlah serum yang dipakai sebanyak 55 sampel terdiri dari 5 sampel negatif HIV hasil uji serologi dengan rapid test dan 50 sampel dengan enzyme linked immunoassay (ELISA). Hasil penelitian menunjukkan pada 55 sampel yang diuji baik dengan teknik RTPCR elektroforesis gel agarosa maupun RT-PCR hibridisasi dot blot, 43 sampel positif mengandung HIV. Hasil RT-PCR hibridisasi dot blot jauh lebih jelas dibanding dengan RT-PCR-elektroforesis gel agarosa. Hal ini terlihat munculnya dot hitam tebal pada film sedangkan pada gel agarosa pita DNA tampak tipis untuk beberapa sampel positif HIV yang sama.

\section{KESIMPULAN}

Skrining HIV dengan menggunakan rapid test menunjukkan hasil negatif pada remaja di Surabaya. Pengujian HIV dengan menggunakan uji serologis dan biologi molekuler dibutuhkan untuk melacak virus HIV. Ini disebabkan tiap pengujian memiliki nilai sensitivitas dan spesivisitas yang berbeda-beda.

\section{DAFTAR PUSTAKA}

Agnes Sri Harti, Amalia Agustin, Siti Mardiyah, Estuningsih, Heni Nur Kusumawati. 2014. Pemeriksaan HIV 1 dan 2 Metode Imunokromatografi Rapid Test sebagai Screening Test Deteksi AIDS. Jurnal Kesmadaska, Januari 2014.

Aroem Naroeni, Hartiyowidi Yuliawuri, Yuliar Budi Hartanto, Yuyun Soedarmono, Budiman Bela, Fera Ibrahim. 2009. Karak- terisasi Galur HIV Indonesia dari Donor Darah dengan Hasil Uji Serologi HIV Indeterminate Makara. Kesehatan, Vol. 13, No. 1, Juni 2009 15-21.

Direktorat Jenderal PP dan PL Kementerian Kesehatan RI. 2012. Laporan Situasi Perkembangan HIV/AIDS di Indonesia s.d. 30 Juni 2012. Jakarta (Indonesia).

Djoerban Z, Djauzi S. "HIV/AIDS di Indonesia”. In: Buku Ajar Ilmu Penyakit Dalam Edisi V. Editor: Sudoyo AW, Setiyohadi B, Alwi I, Simadibrata M, Setiati S. Jakarta: Pusat Penerbitan IPD FKUI. 2009; p. 2861

Direktorat Jenderal PP dan PL Kementerian Kesehatan RI. 2013. Laporan Situasi Perkembangan HIV/AIDS di Indonesia s.d. 31 Maret 2013. Jakarta (Indonesia).

Kelompok Kerja HIV-AIDS. 2005. Remaja Dinilai Rentan Tertular HIV. Jakarta: Rumah Sakit Penyakit Infeksi Prof. Dr. Sulianti Saroso. Diperoleh dari: http://www.aidsrpiss.com.

Keputusan Menteri Kesehatan RI. 2005. Keputusan Menteri Kesehatan Republik Indonesia Nomor 1507/Menkes/SK/X/2005 tentang pedoman pelayanan konseling dan testing HIV/AIDS secara sukarela (Voluntary Counselling and Testing). Jakarta: Menkes RI.

Maria Lina Rosilawati dan Budiman Bela. Teknik Reverse Transcription - Polymerase Chain Reaction (RT-PCR) dan Hibridisasi Dot Blot dengan Pelacak DNA untuk Deteksi Human Immunodeficiency Virus (HIV) dalam Serum Darah Universa Medicina 2007; 26: 111-9.

Riyarto S., Wijayanti Y., Indriani C., Wilasto N., Lazuardi E., Mahendradatta Y. 2010. Faktor-faktor yang Memengarubi Keterlambatan Diagnosis HIV dan AIDS di Yogya- 
karta, Solo, dan Semarang. Yogyakarta: Universitas Gajah Mada.

Siregar, F.A. 2004. Pengenalan dan Pencegahan AIDS (Disertasi). Sumut (Indonesia): Universitas Sumatera Utara.

UNAIDS. 2011. UNAIDS World AIDS Day Report. Geneva (Swizerland).
World Health Organization/UNAIDS. AIDS Epidemic Update, Report on the global AIDS epidemic. Last updated June 28, 2007 WHO. WHO Case Definitions of HIV for Surveilance and Revised Clinical Staging and Immunological Classification of HIV Related Disease in Adult and Children. Geneva (Switzerland). 